Proc. Indian Acad. Sci. (Earth Planet. Sci.), Vol. 94, No. 2, July 1985, pp. 117-128.

(C) Printed in India.

\title{
Summer cooling of the Arabian Sea-a review
}

\author{
J S SASTRY and V RAMESH BABU \\ National Institute of Oceanography, Dona Paula, Goa 403004, India \\ MS received 24 November 1983; revised 31 January 1985
}

\begin{abstract}
The summer cooling of the Arabian Sea has been reviewed in relation to the dynamic and thermodynamic processes. The differences in the quantum of cooling in the coastal regions have been attributed to the variations in the strength of coastal upwelling along the respective coasts. In the central portions of the Arabian Sea, the thickness of the surface layer and the thermal structure appear to be predominantly governed by the turbulent mixing of cold waters entrained into the surface layer in association with the deepening of current shear zone. The surface heat losses during the passage of a cyclone over the east central Arabian Sea account for only $40 \%$ of the total heat change in the surface layer while the rest is lost into the interior. Also presented are climatological mean patterns of the forcing parameters and their variations during certain years.
\end{abstract}

Keywords. Summer cooling; Arabian Sea; turbulent mixing; surface heat losses; climatological mean patterns.

\section{Introduction}

The summer cooling of the Arabian Sea is an anomalous feature in tropical oceans. While water bodies similarly situated geographically show an increase in the sea surface temperature (SST) with the advance of the northern summer, the Arabian Sea surface temperature is known to lower. As the sea surface temperature forms one of the bottom boundary conditions for the development of numerical predictive models of the atmosphere, meteorologists and physical oceanographers are interested in understanding the causative factors for this anomalous behaviour. The available information suggests that the quantum of lowering of sst differs from region to region. Off the coast of Somalia, the sst decrease on occasions has been found to be as high as $10^{\circ} \mathrm{C}$ between May and July while off the west coast of India, it is between 2 to $3^{\circ} \mathrm{C}$. There is a substantial lowering of ssT off the Arabian coast. In the northern regions, the sea warms up with increase in ssT towards the Gulfs of Oman and Persia. In this paper, some of the dynamic and thermodynamic processes are discussed to explain the Arabian Sea cooling and also presented is the variability of the forcing parameters.

\section{Climatological patterns of cooling}

Figures 1a, b and c show the May minus June, May minus July and May minus August sea surface temperatures respectively to exhibit the quantum of cooling over the Arabian Sea based on the mean ssT data (Koninklijk Nederlands Meteorologisch Instituut's Atlas 1952). By June (figure 1a) the cooling is predominant off the Somalia coast and off the southwest coast of India. The presence of an area of zonal minimum 
cooling between $68^{\circ}$ and $72^{\circ} \mathrm{E}$ indicates that the spreading of cold waters off Somalia is confined to the western Arabian Sea in the month of June. In the northern regions the sst increases progressively northward with a maximum increase of $3^{\circ} \mathrm{C}$ in the Persian Gulf. Figure $1 \mathrm{~b}$ shows an intensification of these features in July. Off the Somalia and the Arabian coasts the decrease in SST is more than $4^{\circ} \mathrm{C}$ while off the southwest coast of India, it is higher than $2^{\circ} \mathrm{C}$ separated again by a zonal minimum cooling centred around $70^{\circ} \mathrm{E}$. The zone of increase in sst has shifted northward and by this time, the highest increase is about $4.5^{\circ} \mathrm{C}$ in the Persian Gulf. The May minus August temperature distribution (figure 1c) shows that the maximum cooling exceeding $5^{\circ} \mathrm{C}$ occurs off the Arabian Coast while the other features are almost similar to those in figure $1 \mathrm{~b}$. These suggest that the cooling off the coasts of Somalia, Arabia and southwest India has to be treated separately and spreading of cold waters is limited to the respective regions.

\section{Circulation and resultant surface layer}

\subsection{Mean pattern}

Figure 2a shows the mean surface currents in the Indian Ocean during August according to Deutsches Hydrographisches Institut's Atlas (1960). During the southwest monsoon period, one can visualise a great clockwise circulation in the northwestern region of the Indian Ocean. The mean circulation presented has been derived on the basis of the data collected over several years from ship's logs. As per this circulation

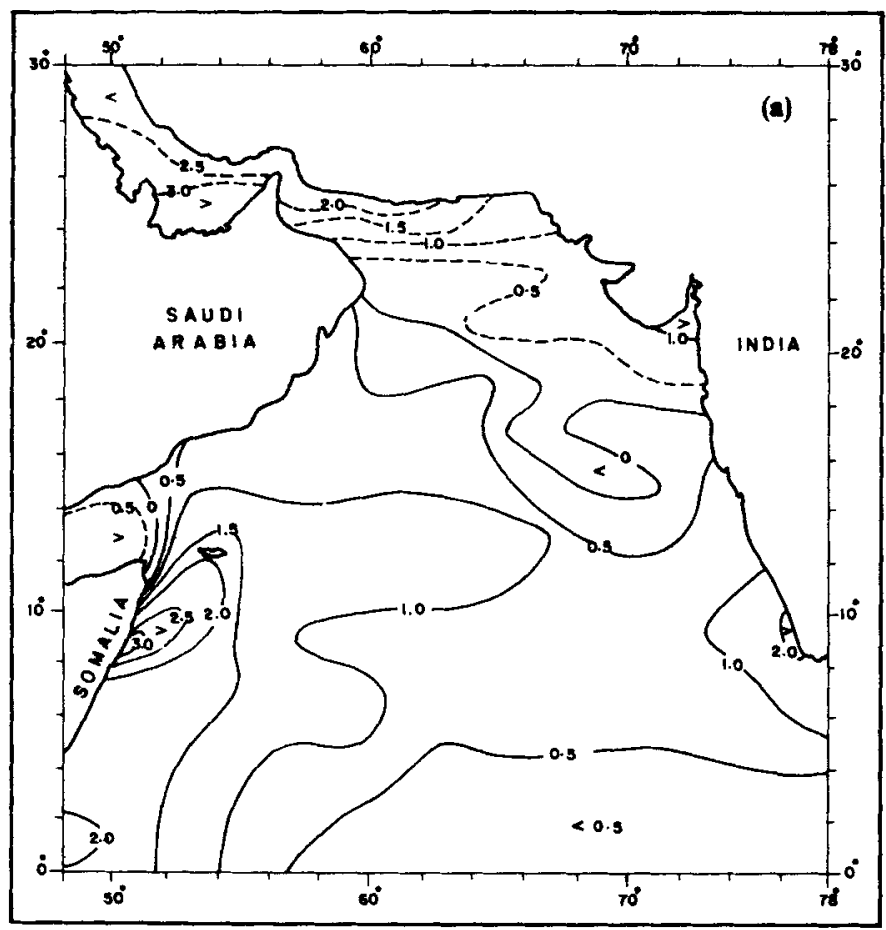

Figure 1a.

May- June 

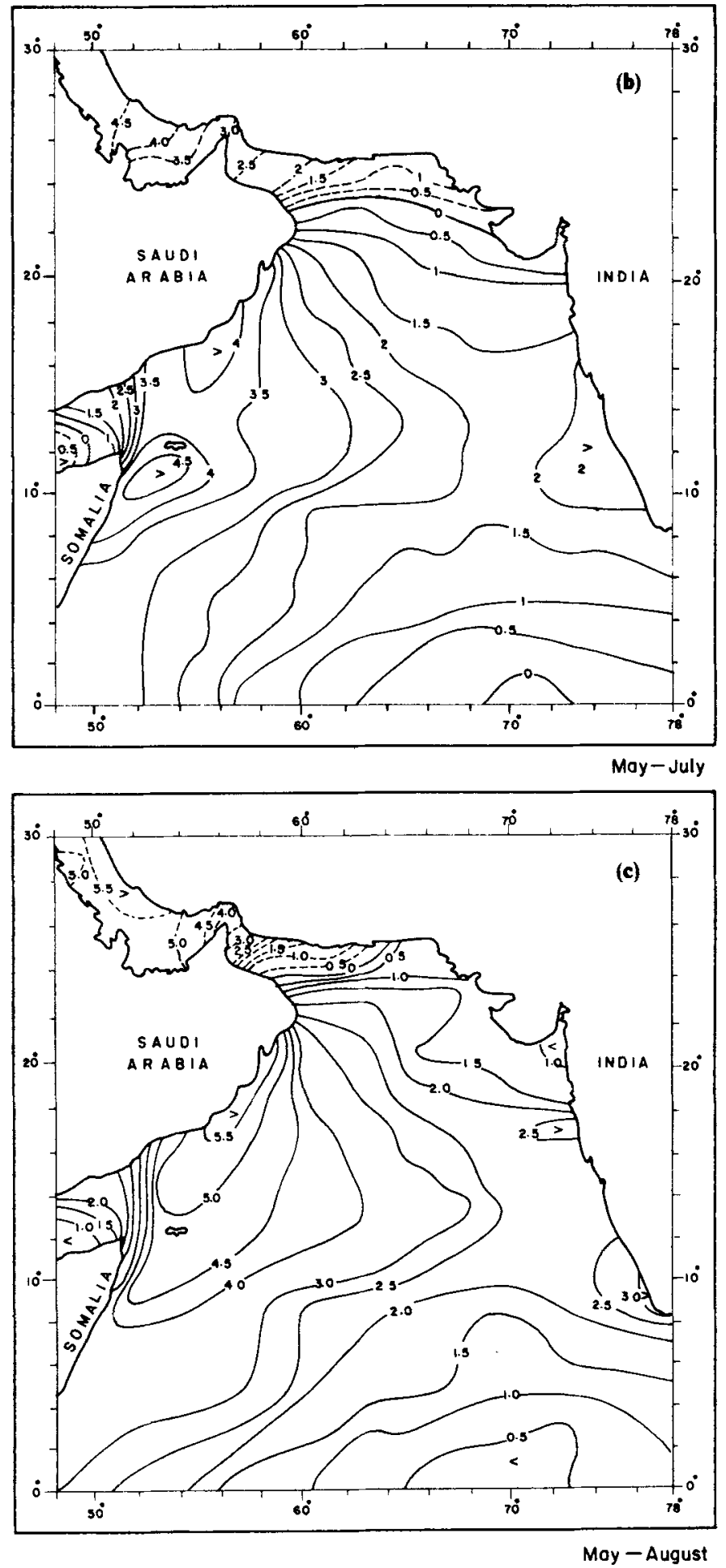

Figure 1. (a) May minus June ssT ( ${ }^{\circ} \mathrm{C}$ ), (b) May minus July sst $\left({ }^{\circ} \mathrm{C}\right.$ ), and (c) May minus August sst $\left({ }^{\circ} \mathrm{C}\right)$ in the Arabian Sea. 

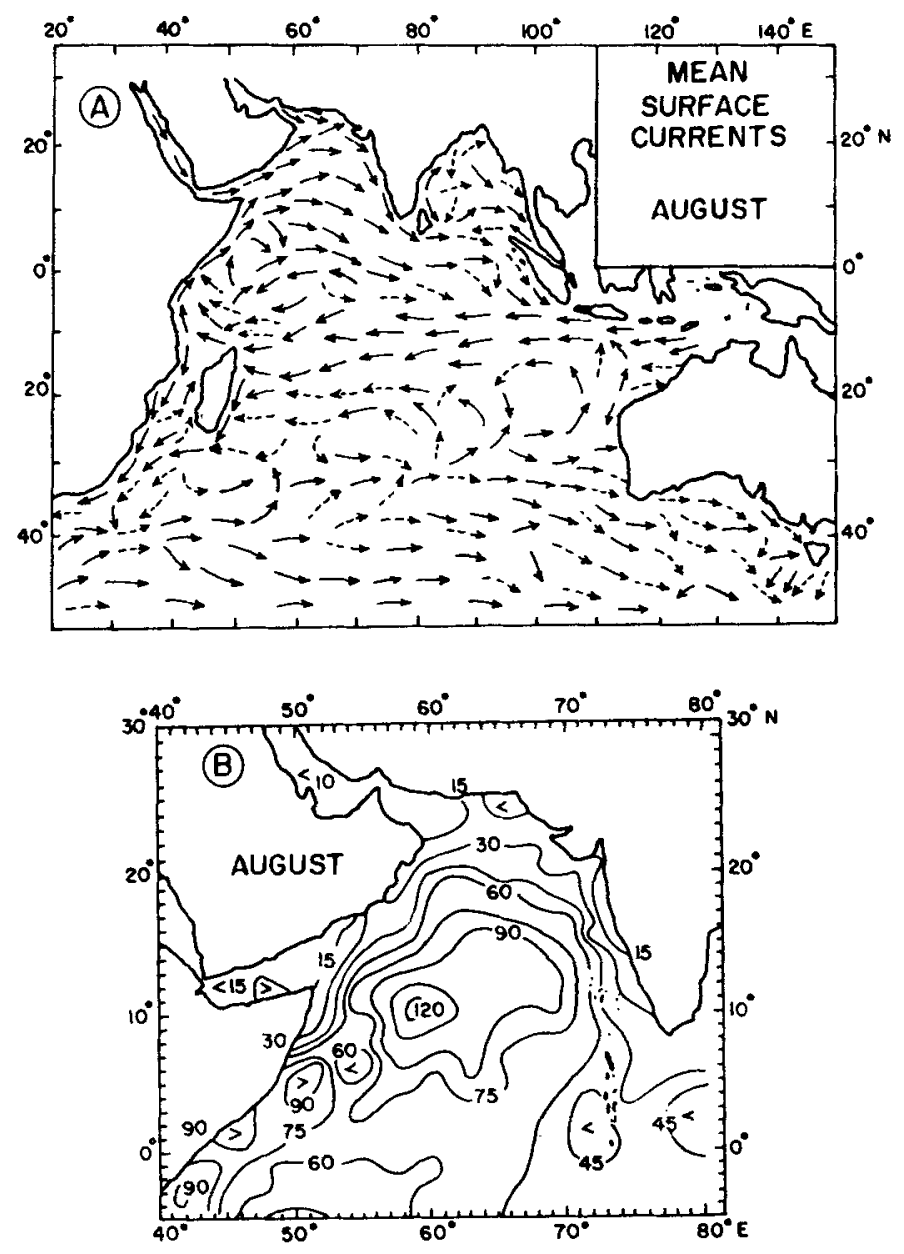

Figure 2. (a) August mean surface currents in the Indian Ocean (after Deutsches Hydrographisches Institut Atlas 1960), and (b) August mean depth (m) of the thermocline in the northwestern Indian Ocean (after Robinson et al 1979).

pattern, one would expect coastal upwelling all along coastal boundaries and hence cooling off Somalia, Arabia and West Coast of India. By June, the Somali current sets in and the process of upwelling is initiated. By July, upwelling intensifies and the coldest temperatures oocur here. This fits into the scheme of things according to which the differential quanta of cooling in different regions over the Arabian Sea are noticed. The figure further suggests that convergence takes place in the central portion of the northwestern Indian Ocean associated with this type of circulation resulting in the increase of the thickness of the surface layer. This is quite evident from figure $2 b$ which shows August mean depths of the top of thermocline in the northwestern Indian Ocean (Robinson et al 1979). The basic features of this figure are: (1) a downward sloping of the thermocline towards west from the west coast of India, (2) a thin surface layer where the Somali current turns eastward around $10^{\circ} \mathrm{N}$ and (3) a relatively shallow thermocline in the northern Arabian Sea. 


\subsection{HOE studies}

The International Indian Ocean Expedition (IIOE) revealed for the first time the complex flow pattern in the Arabian Sea (Bruce 1968; Düing 1970; Sastry and D'souza 1971). The flow patterns consist of a series of clockwise and anti-clockwise gyres in the zonal belt south of $15^{\circ} \mathrm{N}$ in contrast to the climatic features presented in figure $2 \mathrm{a}$. Associated with this type of circulation, one would expect convergences in the clockwise cells and divergences in the anticlock wise cells which govern the thickness of the surface layer. The surface layer deepens in the clockwise cells while in the anticlockwise cells, it shallows up. Figure 3 presents the geostrophic current relative to $1000 \mathrm{db}$ along $10^{\circ} \mathrm{N}$ in the Arabian Sea during the summer monsoon of 1963 (Bruce 1981) which shows alternate bands of north-south flows penetrating deeper upto about $500 \mathrm{~m}$ in the western Arabian Sea. The top of thermocline along the same section shows a wavy pattern with troughs and crests coinciding with the clockwise and anticlock wise gyres. The strength of these cells decreases eastward and the thermocline shows a general upward slope towards the Indian coast. The downward slope of the thermocline to the west off the west coast of India and the very shallow surface layer off Somalia which are seen in the mean patterns could also be seen in figure 3 . Associated with these flows, intense upwelling takes place off Somalia and the spreading of cold waters is seen in the western Arabian Sea only (Sastry and D'souza 1972). The $25^{\circ} \mathrm{C}$ isothermal surface is found cutting the sea surface in the western regions and towards east, this surface is found at depths varying upto $120 \mathrm{~m}$. Recently, Bruce (1981) utilising the XBT data along the tanker route off the African coast has also indicated the possibility of restricted spreading of cold waters under the influence of a large quasipermanent anti-cyclonic eddy found off the Somalia coast.

\section{Wind stress patterns}

The mean pattern of the wind stress curl for the month of July is shown in figure 4a (Bruce 1981) while figure $4 \mathrm{~b}$ shows the wind stress curl for a typical active monsoon day

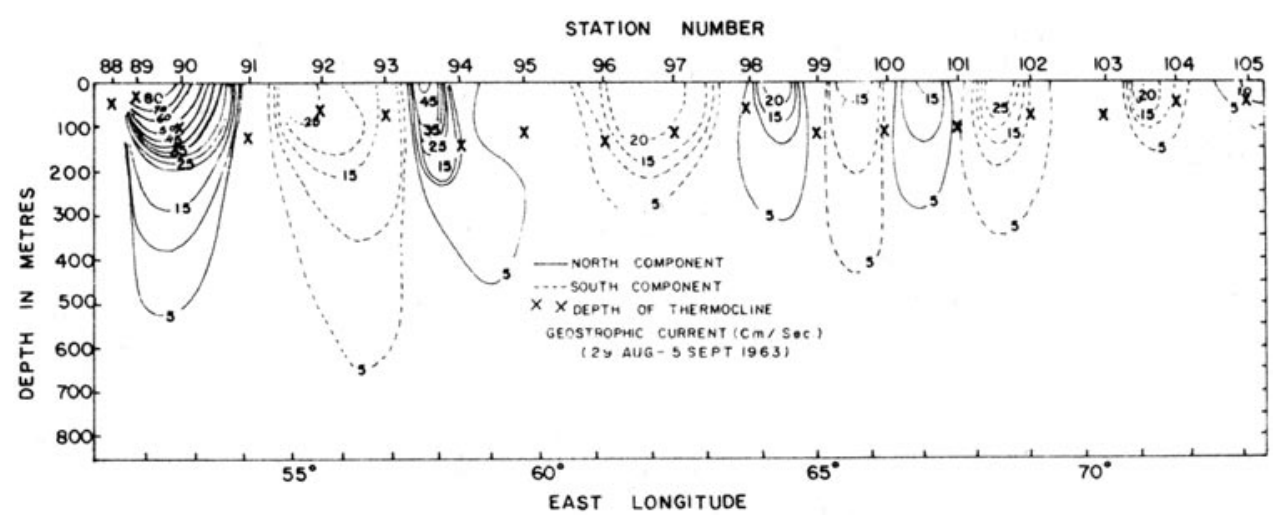

Figure 3. Geostrophic current relative to $1000 \mathrm{db}$ along $10^{\circ} \mathrm{N}$ in the Arabian Sea during summer monsoon season 1963 (after Bruce 1981). 

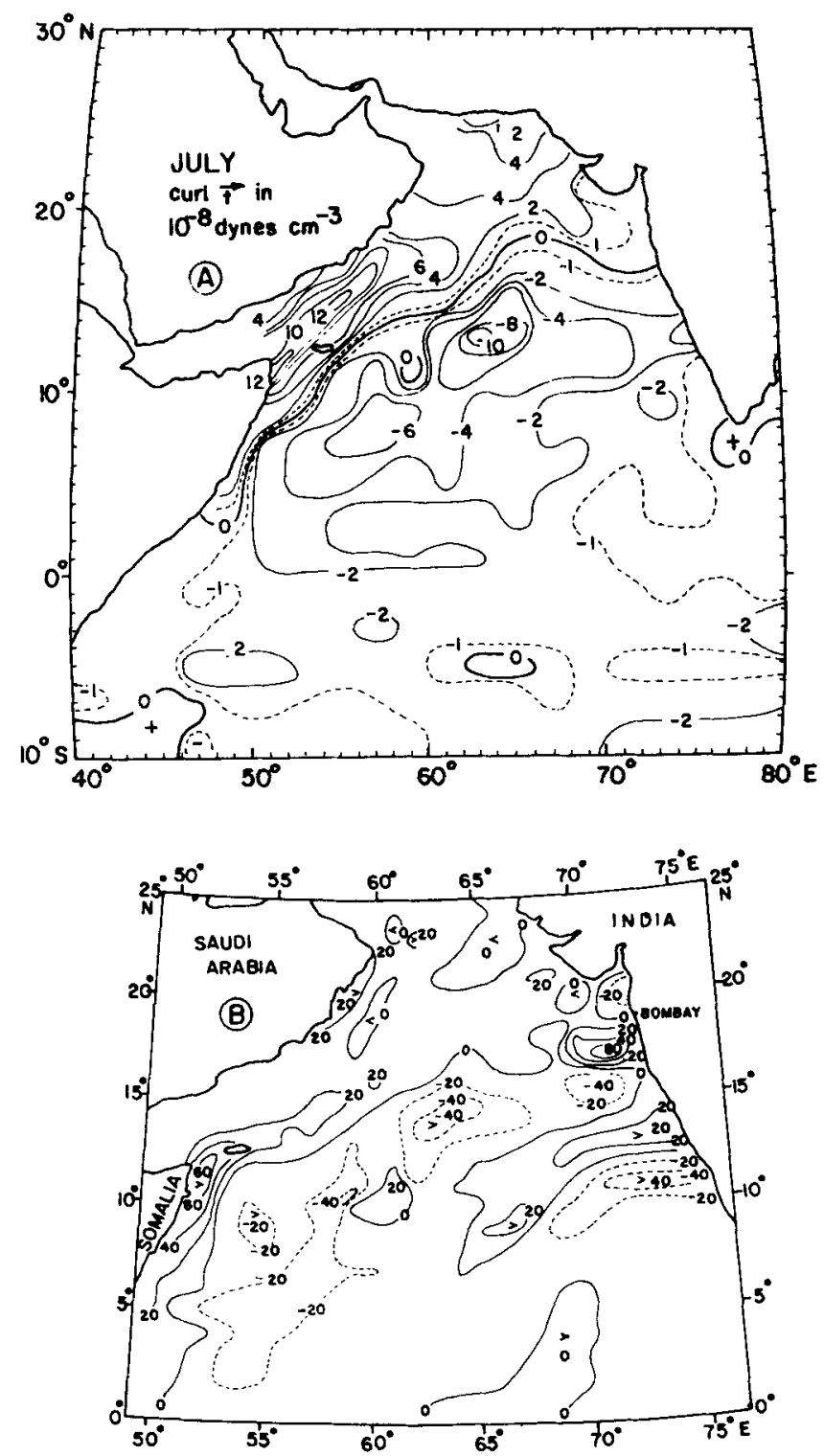

Figure 4. Surface wind stress curl $\left(10^{-8}\right.$ dynes $\left.\mathrm{cm}^{-3}\right)$ over the Arabian Sea. (a) Mean pattern in July (after Bruce 1981), (b) Typical active monsoon day (2nd July, 1963) (after Sastry and Ramesh Babu 1979).

(Sastry and Ramesh Babu 1979). These figures show that the wind stress curl is predominantly negative south of a line joining Somalia coast and Bombay. To the north of this line, it is predominantly positive. These figures suggest that the wind stress curl could be an order of magnitude more in strong monsoon conditions.

One of the major features of atmospheric circulation at the time of the onset of monsoon is the development of vortices over the southeastern Arabian Sea. These may intensify and move either north or northwest. Associated with these circulations, a 
positive wind stress curl would prevail within their active area. As the cyclone intensifies, the wind field over the Arabian Sea not only strengthens but gives rise to a negative wind stress curl in the south-western Arabian Sea (Krishnamurti et al 1981). Thereafter, with the advance of the cyclone and continuation of the active monsoon, the wind stress curl distribution will be as shown in figure $4 \mathrm{~b}$. Figure 5 shows the variation of wind stress curl in the area bounded by $10.5-14.5^{\circ} \mathrm{N}$ lat. and $64-68^{\circ} \mathrm{E}$ long. of the east central Arabian Sea during 1977 monsoon season (Ramesh Babu and Sastry 1984). The positive wind stress curl during 8-11 June, 1977 is due to a cyclone passing through the study area. Subsequently the region has come under the influence of the negative wind stress curl.

Associated with this type of wind stress curl distribution convergences and divergences would develop with consequent vertical velocities which are estimated to be of the order of $10^{-3} \mathrm{~cm} / \mathrm{sec}$ in the Ekman layer (Cox 1970; Sastry and Ramesh Babu 1979). As the wind stress is the main forcing function and as its interannual variability and the variability within the same season are considerable, the near surface circulation patterns could change considerably.

\section{Cooling processes in the eastern Arabian Sea}

The negative wind stress curl gives rise to the development of a strong southerly current off the west coast of India with a consequent upsloping of thermocline towards the Indian coast. This results in an apparent upwelling close to the Indian coast and sinking farther off-shore. Figure 6 shows the evolution of the thermal structure during 1977 monsoon season at $12.5^{\circ} \mathrm{N}$ and $68^{\circ} \mathrm{E}$ (Ramesh Babu and Sastry 1984). The thickness of surface layer, which is around $40 \mathrm{~m}$ before the onset of the monsoon, increases to about $100 \mathrm{~m}$ by mid July. The depth-temperature profile on June 10 shows a slight decrease in SST as well as a slight rising of the thermocline. As mentioned earlier, this region has come under the influence of positive wind stress curl around that time associated with the cyclone. The slight rise in the thermocline could be interpreted as due to upwelling associated with the cyclonic motion. The lowering of ssT by $0.6^{\circ} \mathrm{C}$ could be partly due to surface heat losses. Further deepening of surface layer and further cooling seem to be associated with the dynamic processes at the thermocline such as the entrainment of cold sub-surface waters by vertical current sheer instability. Figures $7 a$ and $b$ show the SST, spot currents and the thickness of surface layer around the same area prior to and after the onset of monsoon respectively. The most important features to note in figure 7 are: (1) deepening of surface circulation whereby the current shear zone is shifted from about $50 \mathrm{~m}$ to more than $100 \mathrm{~m}$, (2) a slight decrease in the surface layer thickness on 10 June, (3) a gradual increase in the thickness of surface layer as well as a decrease in surface temperature thereafter. With the shift of the current shear zone to deeper levels, the cold subsurface waters are entrained into the surface layer and further mixing reduces the sst and also increases the thickness of surface layer.

During Monex '79 experiment, the evolution of depth-temperature profiles in the east central Arabian Sea from 24 May-1 July, 1979 has been studied (Murty et al 1983; Ramesh Babu and Sastry 1984). Their studies indicate a drop in sst by about $1 \cdot 2^{\circ} \mathrm{C}$ immediately after the cyclone has passed over the area on $18 \mathrm{June}$. As noted earlier, the thermocline slightly rises upward. By July, the sst falls by $2.5^{\circ} \mathrm{C}$ from the maximum temperature occurring on 9 th June. Initially before the onset of monsoon, the surface 


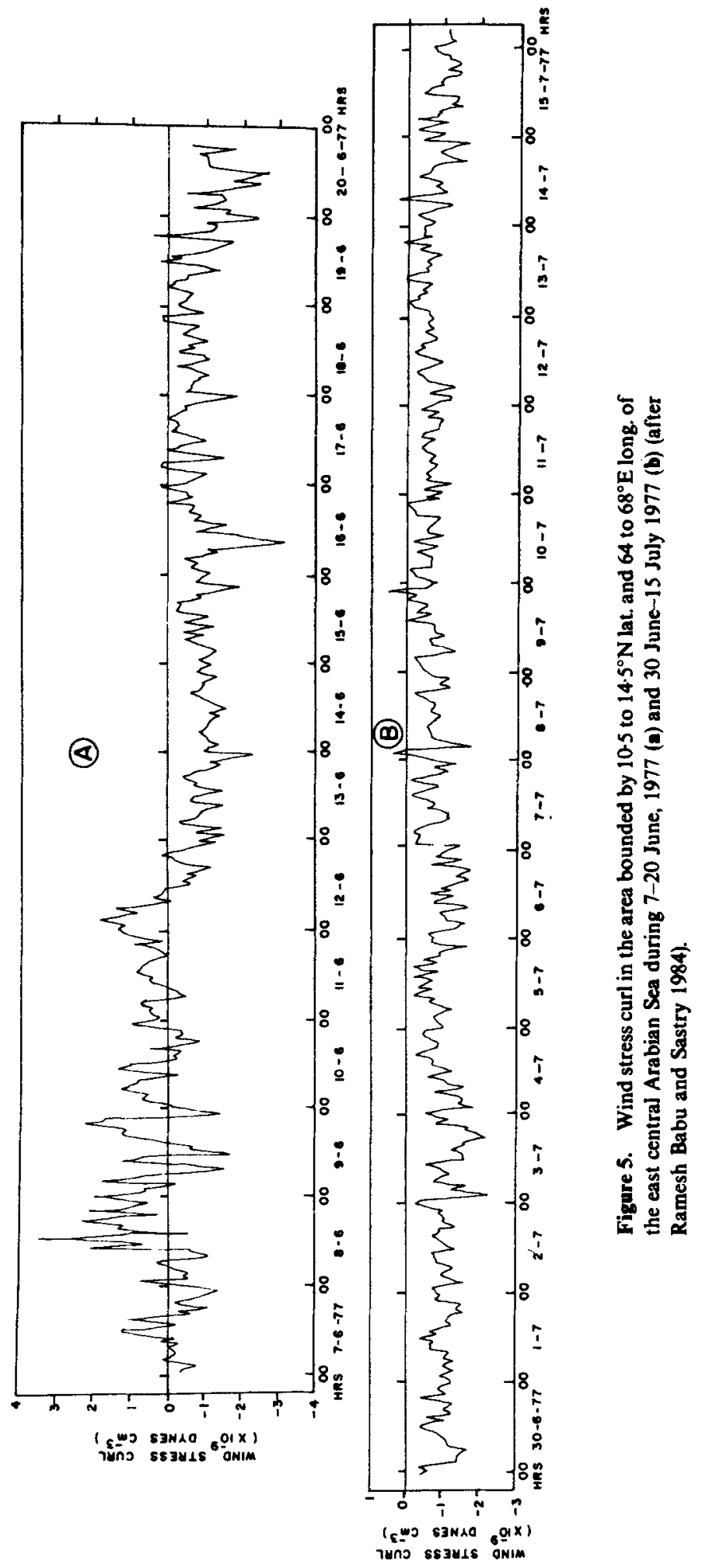




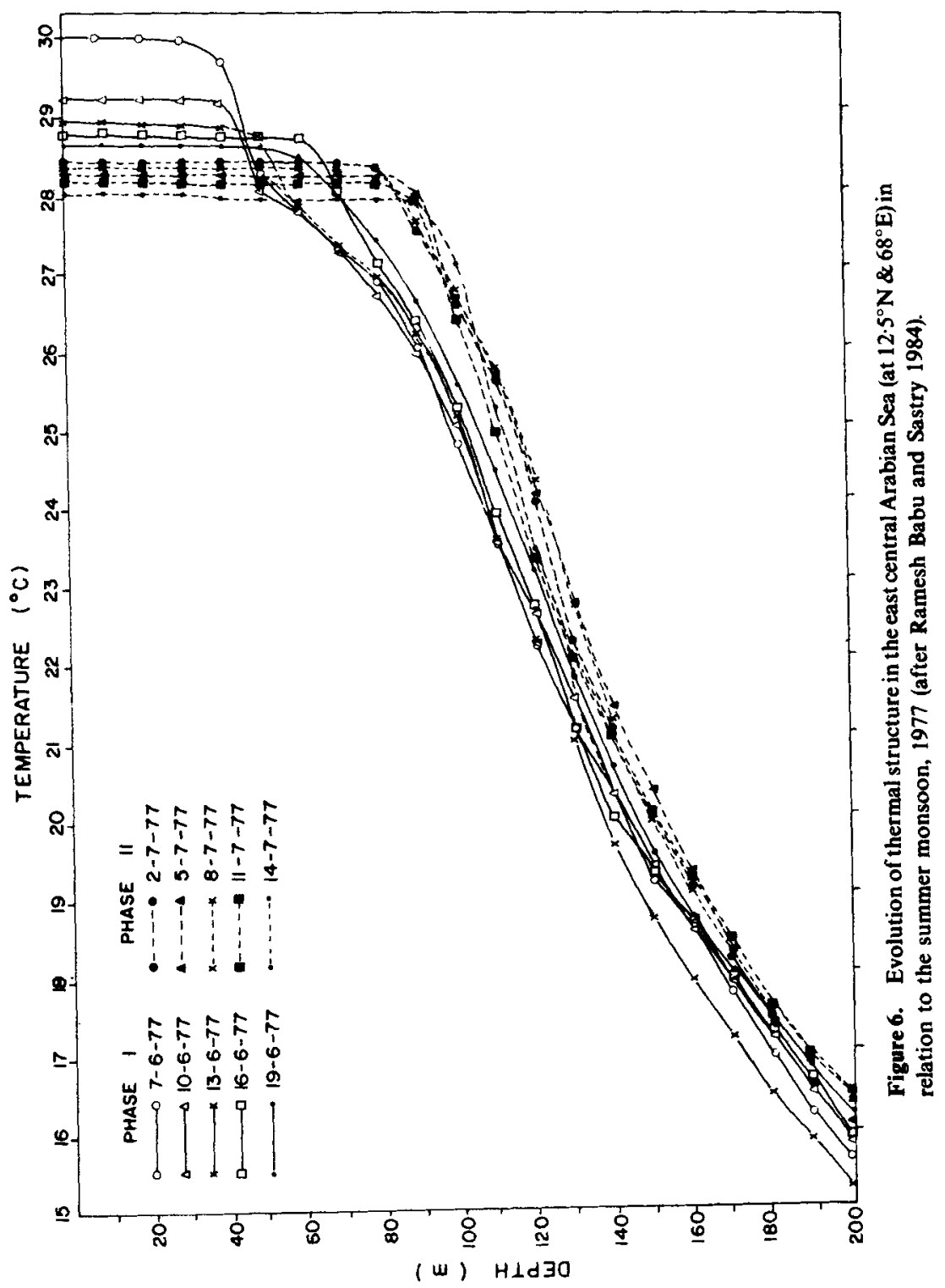




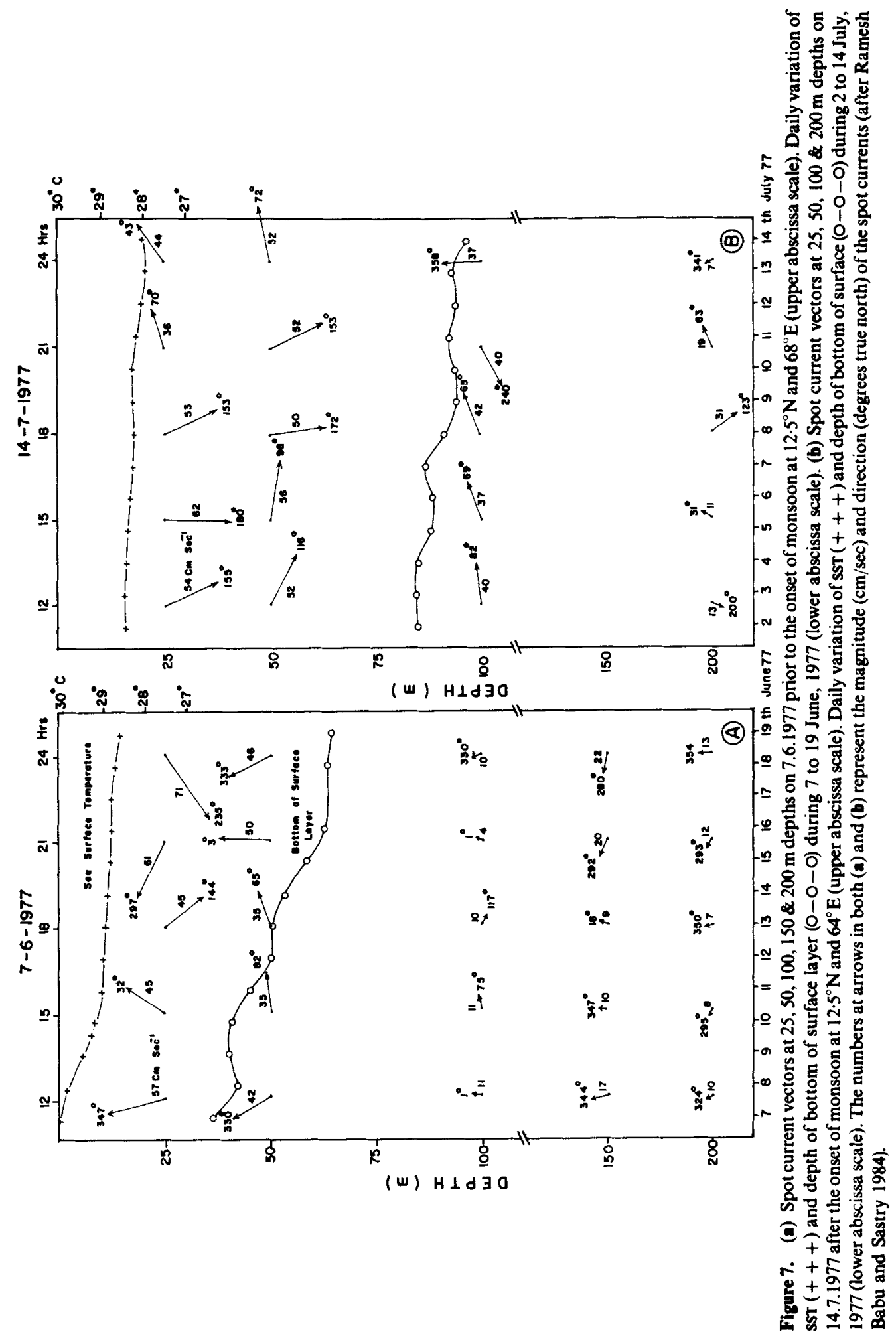


Table 1. Estimation of heat energy lost during 15-17 June, 1979

\begin{tabular}{ll} 
Total energy lost in the surface layer & $Q_{T}=4370 \mathrm{Cal}$ \\
(40 m thickness) & $Q_{e}=1420 \mathrm{Cal}$ \\
Energy lost by evaporation & $Q_{s}=270 \mathrm{Cal}$. \\
$\begin{array}{l}\text { Energy lost by sensible heat } \\
\text { Energy lost by effective back }\end{array}$ & $Q_{b}=129 \mathrm{Cal}$. \\
radiation & $Q_{A}=1819 \mathrm{Cal}$. \\
Total energy lost across the sea surface $\left(Q_{e}+Q_{s}+Q_{b}\right)$ & $Q_{T}-Q_{A}=2551 \mathrm{Cal}$. \\
$\begin{array}{l}\text { Energy lost from surface layer due } \\
\text { to interior oceanic processes } \\
\text { (predominant downward flux) }\end{array}$ & \\
\hline
\end{tabular}

(After Murty et al 1983)

layer is not well defined. After the cyclone has passed over the area and after the monsoon has stabilised, a well defined surface layer forms. Near the coast, the surface layer is $50 \mathrm{~m}$ thick and the thickness of surface layer is $70 \mathrm{~m}$ at about $150 \mathrm{~km}$ farther west. This is the result of the development of the slope of the thermocline associated with the southerly flow.

The rate of evaporation over the east central Arabian Sea during 8-15 June 1979 has averaged to $0.5 \mathrm{~cm} \mathrm{day}^{-1}$ till the area came under the influence of the cyclone and later a sharp increase in the rate of evaporation exceeding $1 \mathrm{~cm}^{\text {day }}{ }^{-1}$ is seen (Murty et al 1983). The total heat losses due to evaporation, back radiation and sensible heat transfer during 15-17 June, 1979 have been computed. A balance was sought between the total surface heat losses and the change in the heat storage in the surface layer. The surface heat losses accounted for only about $40 \%$ of the total heat loss in the surface layer. The balance is the amount of heat lost to the interior of the ocean due to mixing across the thermocline (table 1).

\section{Conclusion}

The entrainment of cold waters into the surface layer and the subsequent turbulent mixing play a dominant role in decreasing the ssT in the east central Arabian Sea. In the western Arabian Sea upwelling and spreading of cold upwelled waters off Somalia and Arabia are the major processes for lowering the ssT.

The Persian Gulf water, which is warmer and saltier due to high evaporation, penetrates into the Arabian Sea at depths of $200-300 \mathrm{~m}$ where its heat is given to the environment. Similarly the Red Sea water penetrates at depths of $600-800 \mathrm{~m}$. Their contribution to the overall heat budget of the Arabian Sea needs to be studied. A survey over the Arabian Sea with four or five research aircrafts equipped with dropsondes, airborne expendable bathythermographs and velocity profiling systems together with a few research ships occupying fixed positions would be extremely useful.

\section{Acknowledgement}

The authors thank Dr V V R Varadachari for his keen interest. 


\section{References}

Bruce J G 1968 Deep-Sea Res. 5665

Bruce J G 1981 Variations in the thermal structure and wind field occurring in the western Indian Ocean during monsoons, Naval Oceanographic Office Tech. Rep. No. 272, Dept. of Navy, NSTL Station, St. Louis

Cox M D 1970 Deep-Sea Res. 1747

Deutsches Hydrographisches Institut 1960 Monatskarten für den Indischen Ozean Publ. No. 2422, Hamburg

Düing W 1970 The monsoon regime of the currents in the Indian Ocean (Honolulu: East-West Centre Press)

Koninklijk Nederlands Meteorologisch Instituut 1952 Indische Ocean oceanografische en meteorologische gegevens, 2nd Ed., Publ. No. 135, De Bilt.

Krishnamurti T N, Ardanuy P, Ramanathan Y and Pasch R 1981 Mon. Weather Rev. 109344

Murty V S N, Rao D P and Sastry J S 1983 Mahasagar-Bull. natn. Inst. Oceanogr. In 'ia., 1667

Ramesh Babu V and Sastry J S 1984 Mausam 3517

Robinson M K, Bauer R A and Schroeder E H 1979 Atlas of North Atlantic-Indian Ocean monthly mean temperatures and mean salinities of the surface layer, Naval Oceanographic Office Rep. Pub. 18, Dept. of Navy, Washington.

Sastry J S and D'souza R S 1971 Indian J. Meteorol. Geophys. 2223

Sastry J S and D'souza R S 1972 Indian J. Mar. Sci. 117

Sastry I S and Ramesh Babu V 1979 Mahasagar-Bull. natn. Inst. Oceanogr. India 12201 